\title{
Evaluation of common bean morphological traits identifies grain thickness directly correlated with cooking time ${ }^{1}$
}

\author{
Guilherme Godoy dos Santos ${ }^{2}$, Nerinéia Dalfollo Ribeiro ${ }^{2}$, Sandra Maria Maziero²
}

\section{ABSTRACT}

The development of new common bean cultivars with grain characteristics that achieve greater acceptance by consumers and faster cooking time is a recent trend in bean breeding programs. This study aimed at evaluating whether different common bean lines exhibit differences in grain morphological traits and cooking time, investigating the linear relationships between these traits and cooking time, and selecting lines with superior grain commercial characteristics and faster cooking times. A randomized blocks design with three replications was used. Treatments consisted of 14 common bean genotypes grown during two seasons. Differences in the mass of 100 grains and grain length, width, thickness, shape, flatness, percentage of water uptake and cooking time were observed between lines. A high positive correlation was observed between grain thickness and cooking time $(r=0.9727)$. The path analysis revealed that grain thickness had the highest positive direct effect on cooking time (0.62). Therefore, fast-cooking common bean lines can be indirectly selected based on lower grain thicknesses. The DF 06-17 line presents fast-cooking grains with characteristics well accepted by the market and consumers.

KEY-WORDS: Phaseolus vulgaris; path analysis; Pearson correlation; genotype $\mathrm{x}$ environment interaction.

\section{INTRODUCTION}

Breeding programs have devoted great attention to the development of new common bean cultivars with fast-cooking grains and market acceptance. In Brazil, both the packaging industry and consumers prefer the Black and Carioca beans (Carbonell et al. 2010). These beans have mass of 100 grains of 25-30 $\mathrm{g}$ and elliptical and semi-full grains.

Common bean lines and cultivars with cooking times between 12 and 26 minutes were

\section{RESUMO}

Avaliação de caracteres morfológicos de feijão comum identifica espessura do grão diretamente correlacionada com o tempo de cozimento

O desenvolvimento de novas cultivares de feijão comum que atendam à demanda de padrão de grãos com maior aceitação para o consumo e de cozimento rápido é uma tendência recente em programas de melhoramento. Objetivou-se verificar se há diferenças entre linhagens de feijão comum, quanto aos caracteres morfológicos de grãos e tempo de cozimento, investigar as relações lineares entre esses caracteres e o tempo de cozimento e selecionar linhagens superiores em padrão comercial de grão e de rápido cozimento. O experimento foi conduzido em delineamento de blocos ao acaso, com três repetições. Os tratamentos consistiram de 14 genótipos de feijão, em duas épocas de cultivo. As linhagens diferiram quanto à massa de 100 grãos, comprimento, largura, espessura, forma, achatamento, porcentagem de absorção de água e tempo de cozimento dos grãos. Estimativa de correlação positiva e de alta magnitude foi obtida entre a espessura dos grãos e o tempo de cozimento $(r=0,9727)$. Na análise de trilha, constatou-se que a espessura dos grãos apresentou o maior efeito direto positivo sobre o tempo de cozimento $(0,62)$. Portanto, linhagens de feijão comum de cozimento rápido podem ser selecionadas indiretamente, com base na menor espessura do grão. A linhagem DF 06-17 apresenta padrão de grão aceito pelo mercado e consumidor e rápido cozimento.

PALAVRAS-CHAVE: Phaseolus vulgaris; análise de trilha; correlação de Pearson; interação genótipo x ambiente.

recently released by different breeders (Corrêa et al. 2010, Farinelli \& Lemos 2010, Oliveira et al. 2012, Mingotte et al. 2013, Ribeiro et al. 2013 and 2014). Common bean cultivars that reach the ideal softness for consumption after 15 to 30 minutes of cooking in a pressure cooker have higher market acceptance because they require lower energy expenditure (gas or electrical) and less time for meal preparation.

However, bean-cooking times can vary with the cultivation environment and genotype $\mathrm{x}$ environment interaction (Rodrigues et al. 2005a, 
Farinelli \& Lemos 2010, Perina et al. 2014). Beans grown during the rainy season were found to have grains with lower mean cooking times (Perina et al. 2014), however, the opposite has also been observed (Farinelli \& Lemos 2010). Moreover, bean-cooking time has been observed to decrease with higher water availability during the pod-filling period (Rodrigues et al. 2005a). Therefore, the genotype $x$ environment interaction should be further investigated to evaluate the possibility of selecting lines with desirable grain morphological traits and fast-cooking times.

The registration of new common bean cultivars requires the evaluation of bean-cooking time (Brasil 2006). Bean-cooking time is determined using a Mattson cooker (Proctor \& Watts 1987). However, this is a destructive and time-consuming method, and requires high-energy consumption, which limits its inclusion in the routine of breeding programs. This problem is especially important in the initial steps of the selection process, such as the evaluation of segregating generations.

In early generations, the number of available seeds is usually low and the number of different progenies to be evaluated is high. In this scenario, identifying grain morphological traits that are highly correlated with cooking time would quickly enable the indirect selection of fast-cooking common bean lines, and without destruction of the evaluated grains. However, no reports of correlations between cooking time and grain morphological traits, such as size and shape for common beans, have been found in the literature.

This study aimed at evaluating whether different common bean lines have differences in grain morphological traits and cooking times, investigating the linear and direct/indirect relationships between these morphological traits and cooking times, and selecting lines with fast-cooking grains and superior commercial characteristics.

\section{MATERIAL AND METHODS}

The experiments were conducted at the Universidade Federal de Santa Maria, in Santa

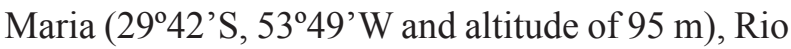
Grande do Sul State, Brazil, where the climate is Cfa (subtropical humid with hot summers and without a well-defined dry season), according to the Köppen classification. The soil is a typical Alitic Argisol, and was prepared according to conventional cultivation practices.
A randomized blocks design with three replications was used. Treatments consisted of 14 common bean genotypes. Four genotypes were control cultivars (BRS Valente, Guapo Brilhante, Pérola and Carioca), and the following 10 inbred lines originated from a Use and Cultivation Value (UCV) trail in Southern Brazil: CNFC 10762, CNFP 10794 (Embrapa Arroz e Feijão), LP 09-192, LP 09-40 (Instituto Agronômico do Paraná - Iapar), DF 06-09, DF 06-17 (Universidade Federal de Santa Maria UFSM), GEN C4-7-8-1-2, GEN C4-7-7-2-2 (Instituto Agronômico de Campinas - IAC), CHC 98-42 and CHP 01-238 (Empresa de Pesquisa Agropecuária e Extensão Rural de Santa Catarina - Epagri). All genotypes evaluated belong to the Mesoamerican gene pool and are representatives of the most consumed bean types in Brazil: Black and Carioca (beige seed coat with brown stripes). The CHP 01-238, DF 06-17, LP 09-192 and CNFP 10794 lines and Guapo Brilhante and BRS Valente cultivars have grains with a black seed coat, whereas the remaining tested genotypes are Carioca-type beans. The experimental unit consisted of four rows (4 m length) spaced $0.5 \mathrm{~m}$ apart. The two central rows of each plot were considered the useful area $\left(4 \mathrm{~m}^{2}\right)$.

Sowing was performed on November 7 th (2012) and February 28th (2013), corresponding to the rainy (2012/2 season) and dry (2013/1 season) seasons in Southern Brazil, respectively. Fertilization was applied to the seed rows in amounts based on the soil chemical analysis report. Topdressing nitrogen fertilization was performed at the first trifoliate leaf stage (V3). Pest insects were controlled by the application of $125 \mathrm{~mL} \mathrm{ha}^{-1}$ of thiamethoxam + lambdacyhalothrin. Weeds were removed mechanically as needed to avoid competition with the crop. No disease control was performed.

Plants from the useful area were harvested manually at the over mature pod stage (R9). Impurities and broken grains were removed, and the remaining grains were dried in an oven $\left(65-70{ }^{\circ} \mathrm{C}\right)$ until a mean moisture of $13 \%$ was reached. Three samples of 100 grains were randomly selected from each replicate to determine the mass of 100 grains, and one sample of 10 grains was selected to measure length, width and thickness, using a caliper. Grain shape was evaluated by determining the length to width ratio (coefficient $\mathrm{J}$ ), and grains were classified as spherical (1.16-1.42), elliptical (1.43-1.65), oblong/kidney-shaped short (1.66-1.85), oblong/ 
kidney-shaped medium (1.86-2.00), and oblong/ kidney-shaped long (> 2.00) (Puerta Romero 1961). The degree of flatness (coefficient $\mathrm{H}$ ) was calculated as the thickness to width ratio, and grains were classified as flat $(<0.69)$, half-full $(0.70-0.79)$ and full $(>0.80)$.

The percentage of water uptake was measured in samples of 25 grains per replicate. Every 30 minutes, a grain sample was placed in a plastic cup containing $50 \mathrm{~mL}$ of distilled water and soaked for 8 hours. Then, the grains were removed and partially dried in a paper towel. The percentage of water uptake by the grains was calculated as the difference in grain mass before and after imbibition (Plhak et al. 1989).

Cooking time was determined with the 25 grains used to measure the percentage of water uptake, with a Mattson cooker. The device has 25 pegs of $90 \mathrm{~g}$, and $1.0 \mathrm{~mm}$ of diameter at the tip of the pegs. Each grain was placed under a peg, and the cooker was placed inside a $7 \mathrm{~L}$ pressure cooker, without a lid, containing $3 \mathrm{~L}$ of boiling distilled water. The pressure pan was kept at medium heat. As cooking occurred, the peg fell and perforated the grains. The mean falling time of the first 13 pegs $(50 \%+1)$ was considered the cooking time of each sample and is expressed in minutes and seconds (Ribeiro et al. 2007).

Data were subjected to individual and joint variance analyses for a randomized blocks design. The F test $(\mathrm{p}<0.05)$ was used to evaluate the main fixed effects (genotypes and growing season) and the genotype $\mathrm{x}$ growing season $(\mathrm{G} \times \mathrm{S})$ interaction. Homogeneity of variance was tested using the Hartley's Fmax test (Cruz \& Regazzi 1997). The means for different genotypes were compared using the Scott-Knott test $(\mathrm{p}=0.05)$.
The Pearson correlation coefficients were estimated using the phenotypic correlation matrix. The significance of the correlation coefficients was tested using the Student's $t$ test $(\mathrm{p}<0.05)$. Multicollinearity was tested using the classification by Montgomery \& Peck (1981). Cooking time was analyzed using path analysis, with cooking time as the dependent variable and the remaining quantified traits as explanatory variables. All analyses were performed using the Microsoft Office Excel and Genes software (Cruz 2013).

\section{RESULTS AND DISCUSSION}

The variance of the experimental error for the two growing seasons was homogeneous ( $p>0.05$ ), allowing joint variance analysis for the two growing seasons, for all traits evaluated. The joint variance analysis revealed significant genotype $\mathrm{x}$ growing season interaction $(p<0.05)$ for the mass of 100 grains, grain length, width, degree of flatness (coefficient $\mathrm{H}$ ) and percentage of water uptake (Table 1), indicating that the common bean genotypes responded differently to environmental variations. A significant cultivar $\mathrm{x}$ environment interaction was previously reported for the mass of 100 grains (Ribeiro et al. 2014), degree of grain flatness (Carbonell et al. 2010) and percentage of water uptake (Rodrigues et al. 2005a, Perina et al. 2014), for common bean cultivars grown under different cultivation environments.

Genotype and growing season had significant effects on grain thickness, shape (coefficient J) and cooking time. Although the effect of the growing season was considerable, the genotypes did not show differential behavior with the growing seasons

Table 1. Joint variance analysis for the mass of 100 grains and grain length, width, thickness, shape, flatness, percentage of water uptake and cooking time for common bean genotypes (Santa Maria, Rio Grande do Sul State, Brazil, 2012/2013).

\begin{tabular}{|c|c|c|c|c|c|c|c|c|c|}
\hline \multirow{3}{*}{$\begin{array}{l}\text { Source of } \\
\text { variation }\end{array}$} & \multirow{3}{*}{ df } & \multicolumn{8}{|c|}{ Mean square } \\
\hline & & Mass of 100 grains & Length & Width & Thickness & Shape & Flatness & Water uptake & Cooking time \\
\hline & & $\mathrm{g}$ & & & $\mathrm{mm}$ & & & $\%$ & $\mathrm{~s}$ \\
\hline Block & 2 & 5.6468 & 0.0017 & 0.0003 & 0.0002 & 0.0052 & 0.0014 & 491.1384 & $124,191.2743$ \\
\hline Genotype (G) & 13 & $54.7529 *$ & $0.0093 *$ & $0.0067 *$ & $0.0020 *$ & $0.0582 *$ & $0.0184 *$ & $1,855.2915^{*}$ & $107,337.7840 *$ \\
\hline Season (S) & 1 & $0.0000^{\mathrm{ns}}$ & $0.0030 *$ & $0.0010^{\mathrm{ns}}$ & $0.0120 *$ & $0.0510 *$ & $0.0381 *$ & $2,041.0200 *$ & $2,553,216.2743 *$ \\
\hline $\mathrm{G} \times \mathrm{S}$ & 13 & $24.3772 *$ & $0.0039 *$ & $0.0012 *$ & $0.0003^{\mathrm{ns}}$ & $0.0039^{\mathrm{ns}}$ & $0.0037 *$ & $875.4670^{*}$ & $29,891.1686^{\mathrm{ns}}$ \\
\hline Error & 54 & 6.3012 & 0.0007 & 0.0005 & 0.0003 & 0.0104 & 0.0014 & 79.8322 & $21,767.7177$ \\
\hline Mean & & 18.8286 & 0.8282 & 0.4789 & 0.2828 & 1.7370 & 0.5942 & 79.9357 & $1,255.9429$ \\
\hline CV (\%) & & 13.3320 & 3.1947 & 4.8720 & 5.8343 & 5.8610 & 6.4170 & 11.1776 & 11.7473 \\
\hline
\end{tabular}

*, ns Significant and non-significant, respectively, according to the $\mathrm{F}$ test $(\mathrm{p}=0.05)$. 
for grain thickness, shape and cooking time. The genotype $\mathrm{x}$ growing season interaction was not significant for these traits, enabling the selection of superior genotypes for both growing seasons.

Significant differences among the tested common bean genotypes were observed for all evaluated traits, allowing a selection based on grain morphological traits and cooking time. Significant effects of the common bean genotypes on grain thickness (Ribeiro et al. 2000, Soares Júnior et al. 2012), shape (Ribeiro et al. 2000, Coelho et al. 2007) and cooking time (Ramos Júnior et al. 2005, Corrêa et al. 2010, Oliveira et al. 2012, Mingotte et al. 2013) were previously reported.

The mass of 100 grains varied from $11.50 \mathrm{~g}$ (BRS Valente, 2013/1 season) to $26.83 \mathrm{~g}$ (CNFP 10794, 2013/1 season) (Table 2). Therefore, the grains were classified as small to medium, according to the classification described by Blair et al. (2010). However, common bean breeding programs have prioritized the selection of medium-sized (25-30 g)
Black and Carioca beans, because this size meets the preferences of packaging companies and consumers in Brazil (Carbonell et al. 2010).

The Pérola cultivar, which has a mass of 100 grains between $25.88 \mathrm{~g}$ and $28.50 \mathrm{~g}$ (Ramos Júnior et al. 2005, Soares Júnior et al. 2012, Mingotte et al. 2013), has been used as a standard reference for the grain size with the greatest market acceptance (Carbonell et al. 2010). In the present study, the Pérola cultivar had a mean mass of 100 grains of $18.82 \mathrm{~g}$, which was lower than previously reported for this cultivar (Ramos Júnior et al. 2005, Soares Júnior et al. 2012, Mingotte et al. 2013). The lower mass of 100 grains observed for the Pérola cultivar (and most likely for the remaining evaluated genotypes) may be due to the lower rainfall rate during the pod filling stage (R8) observed for the 2012/2 and 2013/1 seasons (Table 3 ).

Significant differences in grain length, width and thickness were observed among the evaluated genotypes (Table 2) and have been previously

Table 2. Mean* grain thickness, mass of 100 grains, grain length, width, shape, flatness, percentage of water uptake and cooking time for common bean genotypes (Santa Maria, Rio Grande do Sul State, Brazil, 2012/2013).

\begin{tabular}{|c|c|c|c|c|c|c|c|c|c|c|c|c|c|}
\hline \multirow{2}{*}{ Genotype } & \multicolumn{3}{|c|}{ Thickness Mass of 100 grains $(\mathrm{g})$} & \multicolumn{2}{|c|}{ Length (mm) } & \multicolumn{2}{|c|}{ Width (mm) } & \multirow{2}{*}{$\begin{array}{l}\text { Shape } \\
\text { mm }\end{array}$} & \multicolumn{2}{|c|}{ Flatness (mm) } & \multicolumn{2}{|c|}{ Water uptake $(\%)$} & \multirow{2}{*}{$\begin{array}{l}\text { Cooking time } \\
\text { (min and s) }\end{array}$} \\
\hline & $\mathrm{mm}$ & $2012 / 2$ & $2013 / 1$ & $2012 / 2$ & $2013 / 1$ & $2012 / 2$ & $2013 / 1$ & & $2012 / 2$ & $2013 / 1$ & $2012 / 2$ & $2013 / 1$ & \\
\hline Guapo Brilhante & $0.32 \mathrm{a}$ & $15.87 \mathrm{~b}$ & $15.47 \mathrm{c}$ & $0.78 \mathrm{~d}$ & $0.77 \mathrm{~b}$ & $0.44 \mathrm{c}$ & $0.43 \mathrm{~d}$ & $1.79 \mathrm{a}$ & $0.72 \mathrm{a}$ & $0.73 \mathrm{a}$ & $39.24 \mathrm{c}$ & $40.01 \mathrm{c}$ & $25: 08 \mathrm{c}$ \\
\hline CHP 01-238 & $0.30 \mathrm{a}$ & $18.00 \mathrm{~b}$ & $17.80 \mathrm{~b}$ & $0.82 \mathrm{c}$ & $0.81 \mathrm{~b}$ & $0.47 \mathrm{~b}$ & $0.46 \mathrm{c}$ & $1.76 \mathrm{a}$ & $0.61 \mathrm{~b}$ & $0.67 \mathrm{~b}$ & $81.15 \mathrm{~b}$ & $48.08 \mathrm{c}$ & $23: 34 \mathrm{c}$ \\
\hline DF 06-17 & $0.29 \mathrm{a}$ & $18.43 \mathrm{~b}$ & $20.83 \mathrm{~b}$ & $0.80 \mathrm{~d}$ & $0.71 \mathrm{c}$ & $0.49 \mathrm{a}$ & $0.44 \mathrm{~d}$ & $1.62 \mathrm{~b}$ & $0.57 \mathrm{c}$ & $0.71 \mathrm{a}$ & $73.77 \mathrm{~b}$ & $77.10 \mathrm{~b}$ & $22: 47 \mathrm{c}$ \\
\hline LP 09-192 & $0.29 \mathrm{a}$ & $20.33 \mathrm{a}$ & $13.20 \mathrm{c}$ & $0.87 \mathrm{~b}$ & $0.79 \mathrm{~b}$ & $0.54 \mathrm{a}$ & $0.54 \mathrm{a}$ & $1.53 \mathrm{~b}$ & $0.51 \mathrm{c}$ & $0.58 \mathrm{c}$ & $83.90 \mathrm{~b}$ & $98.35 \mathrm{a}$ & $22: 28 \mathrm{c}$ \\
\hline GEN C4-7-8-1-2 & $0.29 \mathrm{a}$ & $21.97 \mathrm{a}$ & $21.60 \mathrm{~b}$ & $0.94 \mathrm{a}$ & $0.91 \mathrm{a}$ & $0.51 \mathrm{a}$ & $0.51 \mathrm{~b}$ & $1.81 \mathrm{a}$ & $0.55 \mathrm{c}$ & $0.60 \mathrm{c}$ & $98.15 \mathrm{a}$ & $104.07 \mathrm{a}$ & $21: 50 \mathrm{c}$ \\
\hline CHC 98-42 & $0.29 \mathrm{a}$ & $20.17 \mathrm{a}$ & $18.60 \mathrm{~b}$ & $0.81 \mathrm{c}$ & $0.83 \mathrm{~b}$ & $0.44 \mathrm{c}$ & $0.48 \mathrm{c}$ & $1.79 \mathrm{a}$ & $0.66 \mathrm{~b}$ & $0.60 \mathrm{c}$ & $82.56 \mathrm{~b}$ & $59.03 \mathrm{c}$ & $20: 30 \mathrm{~b}$ \\
\hline LP 09-40 & $0.29 \mathrm{a}$ & $19.73 \mathrm{a}$ & $19.43 \mathrm{~b}$ & $0.89 \mathrm{~b}$ & $0.79 \mathrm{~b}$ & $0.50 \mathrm{a}$ & $0.45 \mathrm{~d}$ & $1.77 \mathrm{a}$ & $0.56 \mathrm{c}$ & $0.66 \mathrm{~b}$ & $95.71 \mathrm{a}$ & $50.33 \mathrm{c}$ & $58 \mathrm{c}$ \\
\hline Carioca & $0.29 \mathrm{a}$ & $18.97 \mathrm{a}$ & $19.97 \mathrm{~b}$ & $0.83 \mathrm{c}$ & $0.80 \mathrm{~b}$ & $0.48 \mathrm{~b}$ & $0.48 \mathrm{c}$ & $1.71 \mathrm{a}$ & $0.56 \mathrm{c}$ & $0.64 \mathrm{~b}$ & $53.86 \mathrm{c}$ & $78.73 \mathrm{~b}$ & $21: 33 \mathrm{c}$ \\
\hline BRS Valente & $0.28 \mathrm{a}$ & $16.83 \mathrm{~b}$ & $11.50 \mathrm{c}$ & $0.83 \mathrm{c}$ & $0.82 \mathrm{~b}$ & $0.46 \mathrm{~b}$ & $0.48 \mathrm{c}$ & $1.75 \mathrm{a}$ & $0.60 \mathrm{c}$ & $0.62 \mathrm{c}$ & $84.24 \mathrm{~b}$ & $91.19 \mathrm{a}$ & $21: 06 \mathrm{c}$ \\
\hline Pérola & $0.28 \mathrm{a}$ & $19.30 \mathrm{a}$ & $18.33 \mathrm{~b}$ & $0.80 \mathrm{~d}$ & $0.87 \mathrm{a}$ & $0.47 \mathrm{~b}$ & $0.50 \mathrm{~b}$ & $1.72 \mathrm{a}$ & $0.56 \mathrm{c}$ & $0.60 \mathrm{c}$ & $94.01 \mathrm{a}$ & $40.88 \mathrm{c}$ & $20: 16 \mathrm{~b}$ \\
\hline GEN C4-7-7-2-2 & $0.27 \mathrm{~b}$ & $16.03 \mathrm{~b}$ & $12.13 \mathrm{c}$ & $0.84 \mathrm{c}$ & $0.85 \mathrm{a}$ & $0.48 \mathrm{~b}$ & $0.51 \mathrm{~b}$ & $1.71 \mathrm{a}$ & $0.54 \mathrm{c}$ & $0.55 \mathrm{~d}$ & $103.70 \mathrm{a}$ & $73.40 \mathrm{~b}$ & 19:07 b \\
\hline CNFP 10794 & $0.27 \mathrm{~b}$ & $23.97 \mathrm{a}$ & $26.83 \mathrm{a}$ & $0.83 \mathrm{c}$ & $0.88 \mathrm{a}$ & $0.51 \mathrm{a}$ & $0.56 \mathrm{a}$ & $1.60 \mathrm{~b}$ & $0.50 \mathrm{c}$ & $0.50 \mathrm{~d}$ & $101.61 \mathrm{a}$ & $92.95 \mathrm{a}$ & $19: 39 \mathrm{~b}$ \\
\hline CNFC 10762 & $0.26 \mathrm{~b}$ & $17.43 \mathrm{~b}$ & $23.57 \mathrm{a}$ & $0.86 \mathrm{~b}$ & $0.85 \mathrm{a}$ & $0.47 \mathrm{~b}$ & $0.47 \mathrm{c}$ & $1.82 \mathrm{a}$ & $0.56 \mathrm{c}$ & $0.56 \mathrm{~d}$ & $89.04 \mathrm{~b}$ & $104.80 \mathrm{a}$ & $18: 08 \mathrm{a}$ \\
\hline DF 06-09 & $0.24 \mathrm{c}$ & $16.57 \mathrm{~b}$ & $24.33 \mathrm{a}$ & $0.78 \mathrm{~d}$ & $0.83 \mathrm{~b}$ & $0.41 \mathrm{c}$ & $0.44 \mathrm{~d}$ & $1.91 \mathrm{a}$ & $0.53 \mathrm{c}$ & $0.61 \mathrm{c}$ & $107.14 \mathrm{a}$ & $91.15 \mathrm{a}$ & $16: 17 \mathrm{a}$ \\
\hline Mean & 0.28 & 18.83 & 18.83 & 0.83 & 0.82 & 0.47 & 0.48 & 1.73 & 0.57 & 0.61 & 84.86 & 75.00 & $21: 33$ \\
\hline$\overline{C V}(\%)$ & 5.83 & 17.03 & 8.74 & 3.53 & 2.92 & 5.38 & 4.28 & 5.86 & 6.79 & 5.98 & 12.20 & 7.85 & 11.75 \\
\hline
\end{tabular}

* Means followed by the same letter within the same column are not significantly different, according to the Scott-Knott test $(\mathrm{p}=0.05)$.

Table 3. Meteorological data collected for the eighth meteorology district at the Santa Maria Meteorology Station, located at the

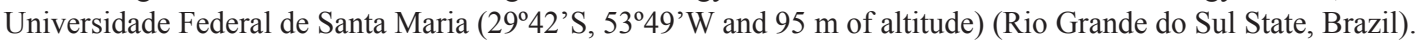

\begin{tabular}{|c|c|c|c|c|c|c|c|c|}
\hline \multirow{2}{*}{ Variable } & \multicolumn{4}{|c|}{ 2012/2 season -} & \multicolumn{4}{|c|}{ 2013/1 season } \\
\hline & Nov & Dec & Jan & Feb & Mar & Apr & May & Jun \\
\hline Minimum temperature $\left({ }^{\circ} \mathrm{C}\right)$ & 17.5 & 19.9 & 18.2 & 19.1 & 16.4 & 14.4 & 11.0 & 9.5 \\
\hline Maximum temperature $\left({ }^{\circ} \mathrm{C}\right)$ & 30.4 & 31.1 & 30.3 & 29.9 & 26.6 & 26.4 & 21.4 & 18.9 \\
\hline Rainfall (mm) & 72.8 & 293.0 & 145.3 & 97.7 & 188.6 & 147.4 & 71.6 & 81.6 \\
\hline Relative humidity (\%) & 70.5 & 77.8 & 75.8 & 80.9 & 83.8 & 83.5 & 87.2 & 89.7 \\
\hline
\end{tabular}


reported between different common bean lines (Ribeiro et al. 2000, Coelho et al. 2007, Soares Júnior et al. 2012). Because the evaluated lines exhibited differences in grain size, lines with grain shapes and degrees of flatness desirable for commercial acceptance could be selected.

The following grain shapes were observed for the different genotypes: elliptical $(\mathrm{J}=1.43-1.65$ : DF 06-17, LP 09-192 and CNFP 10794) and oblong/ kidney-shaped ( $\mathrm{J}=1.66-2.00$ : remaining genotypes). The degrees of grain flatness observed were semi-full $(\mathrm{H}=0.70-0.79$ : Guapo Brilhante for the two growing seasons, and DF 06-17 for the 2013/1 season) and flat $(\mathrm{H}<0.69$ : remaining genotypes $)$. Black and Carioca common beans with elliptical shapes and semi-full profiles are highly valued by the consumer market (Carbonell et al. 2010) and therefore should be prioritized in the selection of superior lines in breeding programs. DF 06-17 was the only line with semi-full elliptical grains, i.e., with grain shape and profile with higher demand in the Brazilian bean market.

The percentage of water uptake varied from $39.24 \%$ (Guapo Brilhante) to $107.14 \%$ (DF 06-09), during the 2012/2 season (Table 2). The new common bean lines and cultivars registered for cultivation in Brazil presented lower variation in percentage of water uptake before cooking, ranging from $88 \%$ to $114 \%$ (Oliveira et al. 2012, Perina et al. 2014). This result can be explained by the fact that grains that $b$ more water following a given period of imbibition usually require less cooking time to reach the softness and texture adequate for consumption (Rodrigues et al. 2005b). In the present study, grains from the Guapo Brilhante cultivar exhibited a low percentage of water uptake for the two growing seasons. This cultivar has grains with a black and shiny seed coat, which somehow resulted in lower permeability of the seed coat to water and higher resistance to water uptake.

The GEN C4-7-8-1-2, CNFP 10794 and DF 06-09 lines exhibited high percentage of water uptake for the two growing seasons, suggesting that their seed coats offered little resistance to water uptake. Therefore, grains from these lines grown during either the rainy or dry season are expected to exhibit fast water uptake when soaked for hours before cooking.

The common bean genotypes evaluated had grain cooking times between 16 min (DF 06-09) and 25 min (Guapo Brilhante) (Table 2). A similar cooking time variation was observed for common bean lines and cultivars recently released by different breeders (Corrêa et al. 2010, Farinelli \& Lemos 2010, Oliviera et al. 2012, Minguotte et al. 2013, Ribeiro et al. 2013, Perina et al. 2014, Ribeiro et al. 2014). This finding shows the investment of breeding programs on the selection of common bean lines with faster cooking times, i.e., those that reach ideal softness under 25 minutes of cooking.

Fast-cooking common bean cultivars are highly demanded by consumers who have little time available to prepare meals and who need to decrease energy consumption. In the present study, the DF 06-09 and CNFC 10762 lines had the lowest cooking times among the lines and cultivars evaluated. Therefore, they hold promise for release as new fast-cooking common bean cultivars.

Grain thickness and cooking time were highly positively correlated $(r=0.9727$; Table 4$)$, indicating that thicker grains require more time to reach the adequate softness for consumption. Grain shape and width $(r=-0.7448)$ and degree of flatness and percentage of water uptake $(r=-0.8334)$ were

Table 4. Pearson correlation coefficients for the relationship between mass of 100 grains, grain length, width, thickness, shape, flatness, percentage of water uptake and cooking time for common bean genotypes (Santa Maria, Rio Grande do Sul State, Brazil, 2012/2013).

\begin{tabular}{|c|c|c|c|c|c|c|c|}
\hline & Length & Width & Thickness & Shape & Flatness & Water uptake & Cooking time \\
\hline Mass of 100 grains & 0.3503 & 0.2420 & -0.3332 & -0.0060 & -0.4152 & 0.3693 & -0.3076 \\
\hline Length & & $0.5613 *$ & -0.1977 & 0.1277 & $-0.5841^{*}$ & $0.5710^{*}$ & -0.2828 \\
\hline Width & & & 0.0678 & $-0.7448 * *$ & $-0.6796 * *$ & 0.4381 & 0.0813 \\
\hline Thickness & & & & -0.2892 & $0.6826^{* *}$ & $-0.6816^{* *}$ & $0.9727 * *$ \\
\hline Shape & & & & & 0.3101 & -0.0289 & -0.3682 \\
\hline Flatness & & & & & & $-0.8334 * *$ & $0.6591 *$ \\
\hline Water uptake & & & & & & & $-0.6787 * *$ \\
\hline
\end{tabular}


Table 5. Path analysis to detect the effect of mass of 100 grains and grain length, width, thickness, shape, flatness, percentage of water uptake on cooking time for common bean genotypes (Santa Maria, Rio Grande do Sul State, Brazil, 2012/2013).

\begin{tabular}{|c|c|}
\hline Trait & Estimate \\
\hline \multicolumn{2}{|l|}{ Mass of 100 grains } \\
\hline Direct effect on cooking time & 0.02 \\
\hline Indirect effect on length & 0.00 \\
\hline Indirect effect on width & 0.04 \\
\hline Indirect effect on thickness & -0.21 \\
\hline Indirect effect on shape & 0.00 \\
\hline Indirect effect on flatness & -0.14 \\
\hline Indirect effect on water uptake & -0.02 \\
\hline Total & -0.31 \\
\hline \multicolumn{2}{|l|}{ Length } \\
\hline Direct effect on cooking time & -0.01 \\
\hline Indirect effect on mass of 100 grains & 0.01 \\
\hline Indirect effect on width & 0.09 \\
\hline Indirect effect on thickness & -0.12 \\
\hline Indirect effect on shape & -0.02 \\
\hline Indirect effect on flatness & -0.20 \\
\hline Indirect effect on water uptake & -0.03 \\
\hline Total & -0.28 \\
\hline \multicolumn{2}{|l|}{ Width } \\
\hline Direct effect on cooking time & 0.15 \\
\hline Indirect effect on mass of 100 grains & 0.00 \\
\hline Indirect effect on length & 0.00 \\
\hline Indirect effect on thickness & 0.04 \\
\hline Indirect effect on shape & 0.13 \\
\hline Indirect effect on flatness & -0.23 \\
\hline Indirect effect on water uptake & -0.02 \\
\hline Total & 0.08 \\
\hline \multicolumn{2}{|l|}{ Thickness } \\
\hline Direct effect on cooking time & 0.62 \\
\hline Indirect effect on mass of 100 grains & -0.01 \\
\hline Indirect effect on length & 0.00 \\
\hline Indirect effect on width & 0.01 \\
\hline Indirect effect on shape & 0.05 \\
\hline Indirect effect on flatness & 0.23 \\
\hline Indirect effect on water uptake & 0.03 \\
\hline Total & 0.97 \\
\hline Determination coefficient $\left(\mathrm{R}^{2}\right)$ & 0.93 \\
\hline Effect of residual variable & 0.26 \\
\hline $\mathrm{K}$ value & 0.05 \\
\hline Condition number & 3079.70 \\
\hline
\end{tabular}

highly negatively correlated. Therefore, the selection for grain shape or degree of flatness may result in decreased grain width and percentage of water uptake. No previous reports of correlations on grain size and shape with water uptake and cooking time were found in the literature.

Grains with a lower thickness were observed to cook faster, and flatter grains absorbed water more quickly. Additionally, a moderate negative correlation was observed between the percentage of water uptake

\begin{tabular}{|c|c|}
\hline Trait & Estimate \\
\hline \multicolumn{2}{|l|}{ Shape } \\
\hline Direct effect on cooking time & -0.17 \\
\hline Indirect effect on mass of 100 grains & 0.00 \\
\hline Indirect effect on length & 0.00 \\
\hline Indirect effect on width & -0.12 \\
\hline Indirect effect on thickness & -0.18 \\
\hline Indirect effect on flatness & 0.11 \\
\hline Indirect effect on water uptake & 0.00 \\
\hline Total & -0.37 \\
\hline \multicolumn{2}{|l|}{ Flatness } \\
\hline Direct effect on cooking time & 0.34 \\
\hline Indirect effect on mass of 100 grains & -0.01 \\
\hline Indirect effect on length & 0.00 \\
\hline Indirect effect on width & -0.11 \\
\hline Indirect effect on thickness & 0.42 \\
\hline Indirect effect on shape & -0.05 \\
\hline Indirect effect on water uptake & 0.04 \\
\hline Total & 0.66 \\
\hline \multicolumn{2}{|l|}{ Water uptake } \\
\hline Direct effect on cooking time & -0.04 \\
\hline Indirect effect on mass of 100 grains & 0.01 \\
\hline Indirect effect on length & 0.00 \\
\hline Indirect effect on width & 0.07 \\
\hline Indirect effect on thickness & -0.42 \\
\hline Indirect effect on shape & 0.00 \\
\hline Indirect effect on flatness & -0.29 \\
\hline Total & -0.68 \\
\hline
\end{tabular}

and cooking time ( $\mathrm{r}=-0.6787$; Table 4$)$. This result is in agreement with Rodrigues et al. (2005b) and indicates that the selection for a fast cooking time might be performed in early generations.

Selecting progenies with grains with a lower thickness and higher flatness is recommended for indirect selection for a fast-cooking time. These evaluations are non-destructive and are easy and fast to perform, enabling the indirect selection of fastcooking progenies. The determination of the grain cooking time is time- and energy-consuming (gas or electrical) and destroys the evaluated grains. Thus, evaluating these morphological traits is indicated for selecting lines in inbred generations.

The multicollinearity analysis revealed a high condition number (Table 5), according to the classification by Montgomery \& Peck (1981). To attenuate the high degree of multicollinearity, the lowest $\mathrm{k}$ value able to stabilize the path coefficient estimates was used $(\mathrm{k}=0.05)$ (Coimbra et al. 2005). 
The path analysis revealed that grain thickness had the highest positive direct effect on cooking time (0.62) (Table 5), with a correlation coefficient that was similar $(r=0.9727)$ in sign and magnitude (Table 4). Therefore, that explains the real relationship between the two traits. The indirect selection of grains with a lower thickness may be an effective method to obtain a larger number of fast-cooking common bean lines in advancing segregating generations.

The remaining evaluated traits had low direct or indirect effects (negative and positive) on cooking time and thus were not adequate for the selection of fast-cooking common bean lines.

\section{CONCLUSIONS}

1. The selection for lower grain thickness is recommended for the indirect selection of fastcooking common bean lines.

2. The DF 06-17 black common bean line has fastcooking grains with commercial characteristics accepted by the market and consumers, and therefore will be selected for the evaluation of its agronomical performance within the breeding program.

\section{ACKNOWLEDGMENTS}

To the Conselho Nacional de Desenvolvimento Científico e Tecnológico (CNPq) and Coordenação de Aperfeiçoamento de Pessoal de Nível Superior (Capes), for the grants awarded.

\section{REFERENCES}

BLAIR, M. W. et al. Genetic diversity, inter-gene pool introgression and nutritional quality of common beans (Phaseolus vulgaris L.) from Central Africa. Theoretical and Applied Genetics, New York, v. 121, n. 2, p. 237-248, 2010.

BRASIL. Ministério da Agricultura, Pecuária e Abastecimento. Requisitos mínimos para a determinação do valor de cultivo e uso de feijão (Phaseolus vulgaris), para a inscrição no Registro Nacional de Cultivares $R C N$. Brasília, DF: MAPA, 2006.

CARBONELL, S. A. M. et al. Tamanho de grão comercial em cultivares de feijoeiro. Ciência Rural, Santa Maria, v. 40, n. 10, p. 2067-2073, 2010.

COELHO, C. M. M. et al. Influência das características morfológicas e físicas dos grãos de feijão (Phaseolus vulgaris L.) na sua capacidade de hidratação e cocção. Revista Brasileira de Biociências, Porto Alegre, v. 5, n. 2, p. 105-107, 2007.

COIMBRA, J. L. M. et al. Consequências da multicolinearidade sobre a análise de trilha em canola. Ciência Rural, Santa Maria, v. 35, n. 2, p. 347-352, 2005.

CORRÊA, M. M. et al. Water absorption, hard shell and cooking time of common beans (Phaseolus vulgaris L.). African Journal of Food Science and Technology, New Delhi, v. 1, n. 1, p. 13-20, 2010.

CRUZ, C. D. Genes: a software package for analysis in experimental statistics and quantitative genetics. Acta Scientiarum Agronomy, Maringá, v. 35, n. 3, p. 271-276, 2013.

CRUZ, C. D.; REGAZZI, A. J. Modelos biométricos aplicados ao melhoramento genético. 2. ed. Viçosa: UFV, 1997.

FARINELLI, R.; LEMOS, L. B. Qualidade nutricional e tecnológica de genótipos de feijão cultivados em diferentes safras agrícolas. Bragantia, Campinas, v. 69, n. 3, p. 759763, 2010.

MINGOTTE, F. L. C. et al. Desempenho produtivo e qualidade pós-colheita de genótipos de feijão do grupo comercial carioca cultivados na época de invernoprimavera. Bioscience Journal, Uberlândia, v. 29, n. 5, p. 1101-1110, 2013.

MONTGOMERY, D. C.; PECK, E. A. Introduction to linear regression analysis. New York: J. Wiley, 1981.

OLIVEIRA, D. P. et al. Qualidade tecnológica de grãos de cultivares de feijão-comum na safra das águas. Semina: Ciências Agrárias, Londrina, v. 33, n. 5, p. 1831-1838, 2012.

PERINA, E. F. et al. Technological quality of common bean grains obtained in different growing seasons. Bragantia, Campinas, v. 73, n. 1, p. 14-22, 2014.

PLHAK, L. C.; CALDWELL, K. B.; STANLEY, D. W. Comparison of methods used to characterize water imbibition in hard-to-cook beans. Journal of Food Science, Chicago, v. 54, n. 3, p. 326-336, 1989.

PROCTOR, J. R.; WATTS, B. M. Development of a modified Mattson bean cooker procedure based on sensory panel cookability evaluation. Canadian Institute of Food Science and Technology Journal, Apple Hill, v. 20, n. 1, p. 9-14, 1987.

PUERTA ROMERO, J. Variedades de judias cultivadas en España. Madrid: Ministério da Agricultura, 1961.

RAMOS JÚNIOR, E. U.; LEMOS, L. B.; SILVA, T. R. B. da. Componentes da produção, produtividade de grãos 
e características tecnológicas de cultivares de feijão. Bragantia, Campinas, v. 64, n. 1, p. 75-82, 2005.

RIBEIRO, N. D.; MELLO, R. M.; STORCK, L. Variabilidade e inter-relações das características morfológicas das sementes de grupos comerciais de feijão. Revista Brasileira de Agrociência, Pelotas, v. 6, n. 3, p. 213-217, 2000.

RIBEIRO, N. D. et al. Padronização de metodologia para avaliação do tempo de cozimento dos grãos de feijão. Bragantia, Campinas, v. 66, n. 2, p. 335-346, 2007.

RIBEIRO, N. D. et al. Combined selection for grain yield, cooking quality and minerals in the common bean. Revista Ciência Agronômica, Fortaleza, v. 44, n. 4, p. 869-877, 2013.
RIBEIRO, N. D. et al. Evaluation of special grains bean lines for grain yield, cooking time and mineral concentrations. Crop Breeding and Applied Biotechnology, Viçosa, v. 14, n. 1, p. 15-22, 2014.

RODRIGUES, J. de A. et al. Qualidade para o cozimento de grãos de feijão obtidos em diferentes épocas de semeadura. Bragantia, Campinas, v. 64, n. 3, p. 369-376, 2005a.

RODRIGUES. J. de A. et al. Correlação entre absorção de água e tempo de cozimento de cultivares de feijão. Ciência Rural, Santa Maria, v. 35, n. 1, p. 209-214, 2005b.

SOARES JÚNIOR, M. S. et al. Características físicas, químicas e sensoriais de feijões crioulos orgânicos, cultivados na região de Goiânia - GO. Revista Verde de Agroecologia e Desenvolvimento Sustentável, Mossoró, v. 7, n. 3, p. 109-118, 2012. 